\title{
Minimally Invasive Temporary Posterior stabilization in Isolated Unstable L5 Burst Fracture with Predominant Radiculopathy: A Case Report
}

\author{
Ajinkya Achalare ${ }^{1}$, Arjun Dhawale ${ }^{1}$, Kshitij Chaudhary ${ }^{1}$, Himanshu Choudhury ${ }^{2}$ \\ Departments of ${ }^{1}$ Orthopaedics, and ${ }^{2}$ Radiology, Sir H.N. Reliance Foundation Hospital, Girgaon, Mumbai, India
}

Corresponding Author: Arjun Dhawale, MS

Department of Orthopaedics, Sir H.N. Reliance Foundation Hospital, Prarthana Samaj, Girgaon, Mumbai, India 400004

Tele: $+91-22-61305047$

Fax: +91-22-35475757

Email: arjundhawale@hotmail.com

Received: December 14, 2020 Revised: February 08, 2021 Accepted: February 21, 2021

\begin{abstract}
To report an isolated L5 burst fracture with predominant radiculopathy treated with MIS, implant removal at one year and its clinical and radiological outcomes at two-year follow-up. A 29-year male sustained an isolated burst fracture of the fifth lumbar vertebra after a train accident. After being treated conservatively at a primary centre for 2 weeks, he presented with back pain with severe radicular pain and hypoesthesia over his left leg. CT and MRI showed a retropulsed fragment with 'reverse cortical sign' causing severe stenosis. As the symptoms were refractory, he was treated with MIS L4-S1 posterior instrumentation without direct decompression, with post-operative resolution of symptoms. The fracture healed and implant removal was done at one year. Clinical and radiological outcomes were evaluated at 2-year follow-up. Results: At 2-year follow-up, Oswestry Disability Index score was 4\%; there was partial remodeling of the spinal canal from $0.5 \mathrm{~cm}^{2}$ to $1.5 \mathrm{~cm}^{2}$, lumbosacral motion of $15.4^{\circ}$, lumbar lordosis of $30.7^{\circ}$, and with $8.7^{\circ}$ loss of segmental L4-S1 lordosis as compared to the immediate postoperative period. In this case of an isolated L5 burst fracture with radiculopathy treated with MIS, there was clinical improvement and motion preservation, with partial remodeling although there was some residual loss of lordosis.
\end{abstract}

Key Words: L5 burst fracture, Minimally invasive surgery (MIS), Implant removal, Canal remodeling

\section{INTRODUCTION}

Burst fractures of the fifth lumbar vertebra are rare, comprising $1.2 \%$ of all fractures of the spine and $2.2 \%$ of fractures of the thoracolumbar region ${ }^{4)}$. They result from an axial compressive force, described first in 1963 by Holdsworth ${ }^{6)}$. In view of the biomechanical stability of the lumbosacral junction due to its protected location below the pelvic brim, more vertically aligned facets, and strong ligamentous attachments, it results from a high impact trauma ${ }^{3-5}$. Generally, conservative management is recommended with surgery being reserved for the patients with significant instability and neurological deficit. Various surgical modalities include spinal decompression with posterolateral or circumferential fusion, corpectomy, and an anterior surgery $^{3-11)}$. There is a single previous report of Minimally Invasive Surgery (MIS) described for L5 burst fracture, however radiological outcomes like the extent of canal remodeling, segmental lordosis, and preservation of lumbosacral motion have not been reported $^{13)}$. We report an isolated unstable L5 burst fracture with predominant unilateral radicular symptoms, managed by posterior MIS stabilization after a conservative trial, implant removal at one year, with outcomes at 2-year follow-up.

\section{CASE REPORT}

A 29-year male was involved in a railway accident, falling between the train and platform. After being managed conservatively at a primary centre for 2 weeks, he presented with back pain and severe left leg radiculopathy, aggravating during movements. He was bowel and bladder continent. On examination, vital parameters were stable; there was axial tenderness over the lumbosacral junction with a hypoesthesia over left S1 dermatome, absent left ankle reflex, and no motor deficit. There were no associated injuries.

Radiology revealed a comminuted L5 burst fracture with retropulsion of the posterosuperior fragment (AO/Magerl type A3.3, Denis burst type A). There was $40 \%$ collapse of the vertebral height with retropulsed fragment demonstrating a 'reverse cortical sign', 90\% stenosis of the central canal, and complete oblite- 
ration of the left lateral recess causing compression of left traversing S1 root (Figure 1, 2).

The patient had been treated conservatively at the primary centre for two weeks with bed rest, intravenous analgesics, and oral pregabalin. As the symptoms were unrelenting, the option of surgical intervention was considered. In view of the predominant instability-associated aggravation of radicular symptoms, MIS posterior L4 to S1 in-situ instrumentation was done on a lordotic frame using DepuySynthes VIPER system with $6 \times 40$ $\mathrm{mm}$ and $35 \mathrm{~mm}$ pedicle screws for $\mathrm{L} 4$ and S1 respectively and $70 \mathrm{~mm}$ connecting rods. No direct or tubular lumbar decompression was performed in view of absence of a motor deficit. The post-operative course was uneventful, mobilization was started the immediate evening, and the patient was discharged within two days.

With the resolution of symptoms and improvement in dermatomal hypoesthesia post-operatively, the patient resumed light work within four weeks of surgery. The post-operative radiograph showed lumbar lordosis of $31.3^{\circ}$ and L4-S1 segmental lordosis of $13^{\circ}$. CT revealed satisfactory implant position although there was no significant change in the position of the retropulsed bony fragment (Figure 3). At 1-year follow-up, radiographs showed a healed L5 fracture with no implant loosening; however L4-S1 segmental lordosis was reduced to $4.4^{\circ}$. Implant removal was done through the previous incisions with a daycare hospitalization in order to preserve the lumbosacral motion segment, as fusion was not performed during the index surgery.

At two-year follow-up, the patient had unrestricted movements and Oswestry Disability Index (ODI) of 4\%. Radiographs
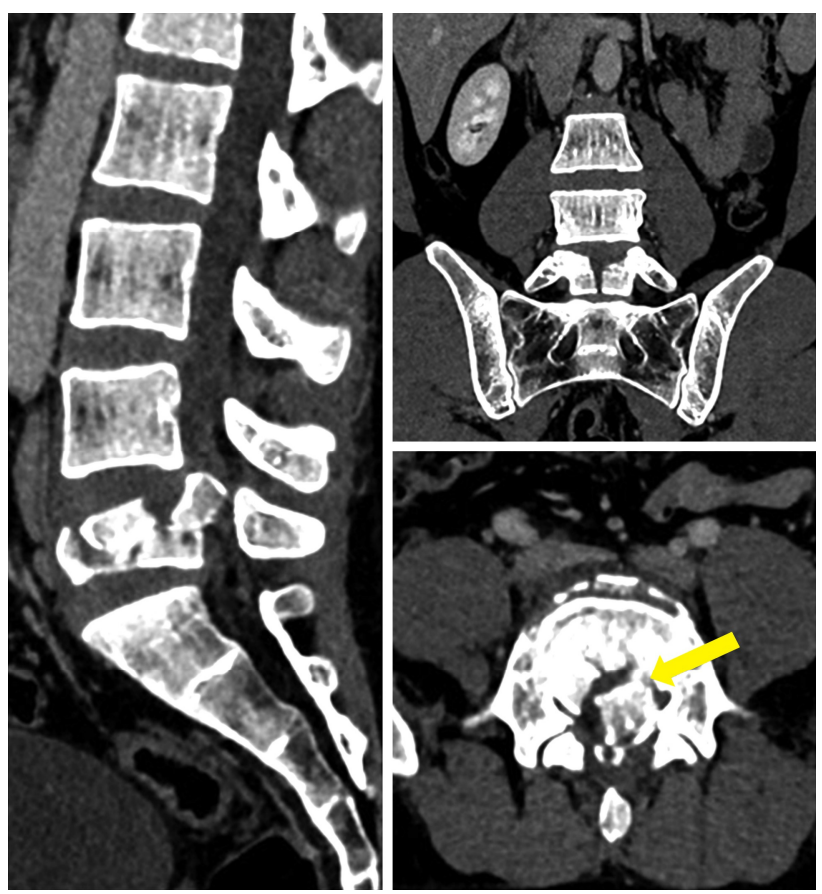

Figure 1. Pre-operative CT scan: Comminuted L5 burst fracture with a sagittal split in the vertebral body. Retropulsed posterosuperior fragment showing 'reverse cortical sign' (yellow arrow). showed healed fracture with $30.7^{\circ}$ of lumbar lordosis, segmental lordosis of $4.3^{\circ}$, and lumbosacral motion of $15.4^{\circ}$ (Figure 4). CT and MRI revealed free lateral recess with the partial remodeling of the central canal from $0.5 \mathrm{~cm}^{2}$ to $1.5 \mathrm{~cm}^{2}$ (Table 1) (Figure 5).

\section{DISCUSSION}

Previously described treatment modalities are summarized in Table $2^{1,3,4,7,8,10-13,16)}$. In 1992, Finn described conservative management in a series of seven patients with L 5 burst fractures, which included immobilization in a cast for two months followed by mobilization with an orthosis for three months. He suggested that the patients with minimal neurological ${ }^{4)}$ involvement could be managed well by conservative methods. Mick et al achieved excellent results with conservative management in patients with intact neurology and canal compromise less than $50 \%$, but recommended surgical intervention in patients with neurological
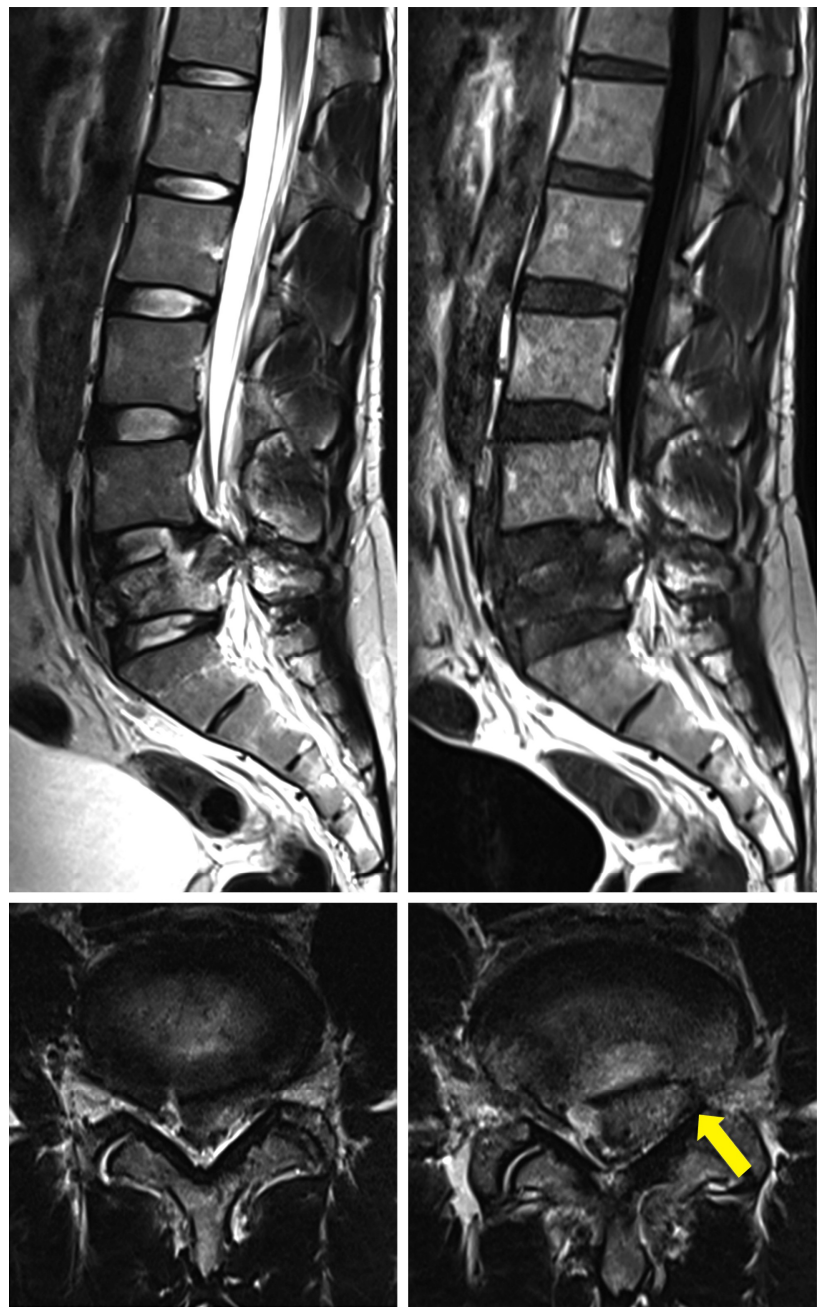

Figure 2. Pre-operative MRI: Retropulsed posterosuperior fragment of L5 vertebra causing 90\% central canal stenosis and complete obliteration of left lateral recess with compression of left traversing S1 nerve root (yellow arrow). 
deficit and severe stenosis ${ }^{11)}$.

Previously described operative modalities include posterior decompression with instrumentation, corpectomy with cage reconstruction, laminotomy for the tapping of fracture fragments followed by percutaneous short segment pedicle fixation, MIS stabilization without direct decompression ${ }^{3,4,7,8,10-13,16)}$. With no fixed algorithm described, surgical intervention needs to be individualized depending on the clinical and radiological presentation. Aggressive decompression like a corpectomy is not indicated in the presence of an intact motor function ${ }^{3,45-8)}$. Posterior stabilization alone provides an inadequate support until the bony healing
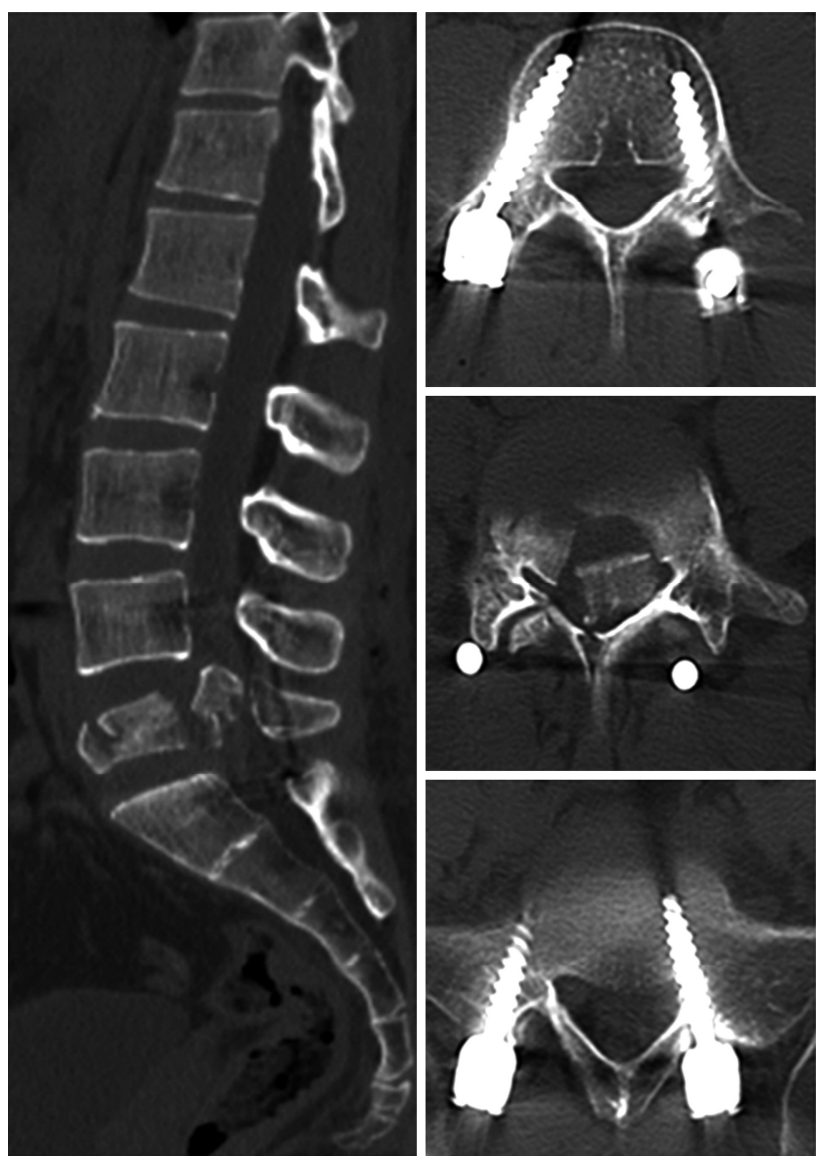

Figure 3. Immediate post-operative CT scan: Well positioned L4 and S1 pedicle screws with persistent retropulsion of the posterosuperior fragment of $\mathrm{L} 5$. occurs $^{9)}$, whereas the anterior approach carries a risk of injury to the large vessels in the proximity ${ }^{2)}$ and the superior hypogastric plexus, which may lead to retrograde ejaculation in males ${ }^{15)}$. The
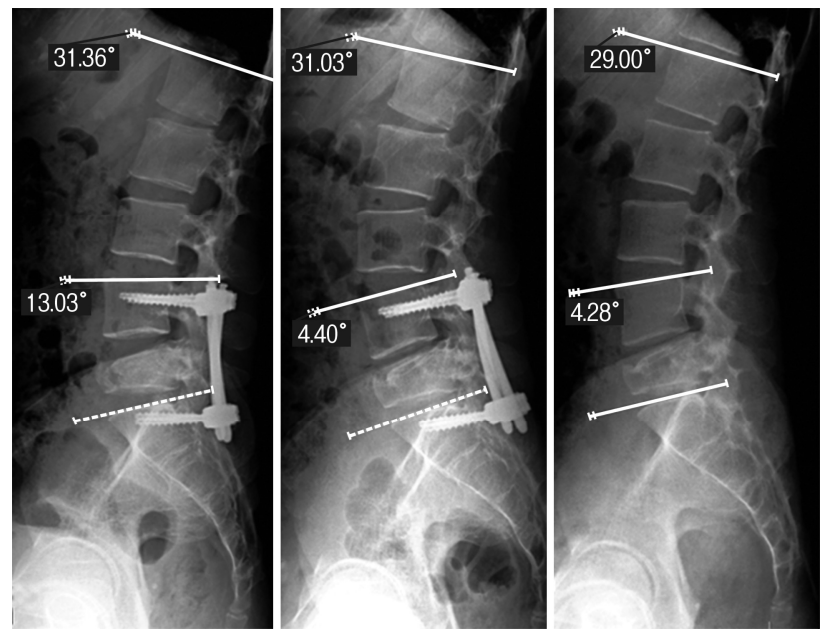

Figure 4. Lateral radiographs of lumbar spine-immediate post-operative, at 1-year and 2-year follow-ups: Reduction of L4-S1 Segmental lordosis from $13^{\circ}$ to $4.2^{\circ}$, whereas overall lumbar lordosis maintained at $29^{\circ}$.

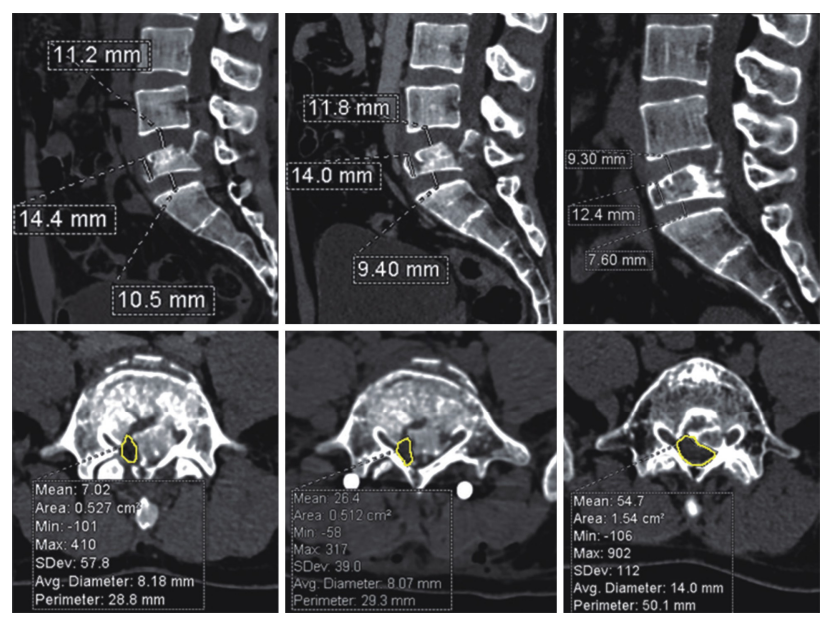

Figure 5. Pre-operative, immediate post-operative and 2-year followup CT (sagittal and axial): Reduction of anterior vertebral height and L4-5, L5-S1 disc heights. Remodeled central canal with volumetric area increased from $0.5 \mathrm{~cm}^{2}$ to $1.5 \mathrm{~cm}^{2}$

Table 1. Radiological parameter evaluation

\begin{tabular}{|c|c|c|c|c|c|}
\hline Modality & Parameter & Pre-operative & Immediate Post-operative & 1-Year follow-up & 2-Year follow-up \\
\hline \multirow{2}{*}{$\begin{array}{l}\text { Erect } \\
\text { radiograph }\end{array}$} & Lumbar lordosis (degree) & - & $31.3^{\circ}$ & $31^{\circ}$ & $29^{\circ}$ \\
\hline & L4-S1 segmental lordosis (Degree) & - & $13^{\circ}$ & $4.4^{\circ}$ & $4.2^{\circ}$ \\
\hline \multirow{4}{*}{ CT scan } & Central canal area $\left(\mathrm{cm}^{2}\right)$ & 0.5 & 0.5 & - & 1.5 \\
\hline & Anterior vertebral height (mm) & 14.4 & 14 & - & 12.4 \\
\hline & L4-5 Disc space height $(\mathrm{mm})$ & 11.2 & 11.8 & - & 9.3 \\
\hline & L5-S1 Disc space height (mm) & 10.5 & 9.4 & - & 7.6 \\
\hline
\end{tabular}


Ajinkya Achalare, et al.

Table 2. Review of literature on L5 burst fractures

\begin{tabular}{|c|c|c|c|c|c|c|}
\hline Author & $\begin{array}{l}\text { No. of Cases } \\
\& \text { Year }\end{array}$ & Mode of Injury & Signs \& symptoms & Treatment & Outcomes & Conclusion \\
\hline Court-Brown ${ }^{3)}$ & $\begin{array}{c}3 \\
(1987)\end{array}$ & $\begin{array}{l}\text { RTA - } 2 \\
\text { Fall from } \\
\text { height - } 1\end{array}$ & $\begin{array}{l}\text { LBP }-3 \\
\text { L4,5 weakness }-2 \\
\text { L5 hypoesthesia }-1\end{array}$ & $\begin{array}{l}\text { Bed rest }+ \text { Brace }-2 \\
\mathrm{PD}+\mathrm{L} 4-\mathrm{S} 1 \text { Fixation with } \\
\text { sacral bar }+ \text { fusion }-1\end{array}$ & $\begin{array}{l}\text { Non-operative: } \\
\text { Complete recovery - } 2 \\
\text { Operative: } \\
\text { IR + BG for pseudoarthrosis at } \\
1 \text { at year. Persistent LBP at } 2 \\
\text { years }\end{array}$ & $\begin{array}{l}\text { Conservative } \\
\text { management preferable } \\
\text { until LS instrumentation } \\
\text { improves }\end{array}$ \\
\hline Finn C. ${ }^{4)}$ & $\begin{array}{c}7 \\
(1992)\end{array}$ & $\begin{array}{l}\text { High impact } \\
\text { trauma }\end{array}$ & $\begin{array}{l}\mathrm{LBP}-7 \\
\mathrm{~L} 5, \mathrm{~S} 1 \text { radicular } \\
\text { pain }-2 \\
\mathrm{~L} 5 \text { weakness }-2\end{array}$ & $\begin{array}{l}\text { Body jacket cast } \\
\text { immobilization for } 8 \text { weeks, } \\
\text { f/b Orthosis for } 3 \text { months }\end{array}$ & \begin{tabular}{|l|} 
Occasional LBP - 7 \\
Persistent deficit - 0 \\
Kyphosis progression - 0
\end{tabular} & $\begin{array}{l}\text { Stable fractures with } \\
\text { minimal neurological } \\
\text { involvement can be very } \\
\text { well treated } \\
\text { conservatively }\end{array}$ \\
\hline Mick C.A. ${ }^{11)}$ & $\begin{array}{c}11 \\
(1993)\end{array}$ & $\begin{array}{l}\text { RTA }-6 \\
\text { Fall from } \\
\text { height }-4 \\
\text { Lifting heavy } \\
\text { weight }-1\end{array}$ & $\begin{array}{l}\text { LBP }-11 \\
\text { Radicular pain - } 4 \\
\text { EHL weakness }-3 \\
\text { L5 hypoesthesia - } 2\end{array}$ & $\begin{array}{l}\text { Bed rest }+ \\
\text { Body cast/TLSO }-5 \\
\text { PD + Fixation }-6 \\
\text { (Coutrel-Dubousset } \\
\text { instrumentation }-4, \\
\text { Steffee plate- }- \text { 2) }\end{array}$ & $\begin{array}{l}\text { Non-operative: } \\
\text { Recovery- } 4 \\
\text { Delayed fixation for persistent } \\
\text { radicular pain \& deficit - } 1 \\
\text { Operative: Recovery- } 5 \\
\text { IR for local pain-1 }\end{array}$ & $\begin{array}{l}\text { Excellent results in } \\
\text { young pts with minimal } \\
\text { canal compromise. } \\
\text { Chances of neurological } \\
\text { recovery greater with } \\
\text { surgery. }\end{array}$ \\
\hline Kaminski A. & $\begin{array}{c}10 \\
(2002)\end{array}$ & $\begin{array}{l}\text { Fall from } \\
\text { height - } 5 \\
\text { RTA - } 3 \\
\text { Direct hit - } 2\end{array}$ & $\begin{array}{l}\text { LBP }-10 \\
\text { L5 weakness - } 2\end{array}$ & $\begin{array}{l}\text { AO internal fixator }+ \text { PLF }+ \\
\text { Transpedicular BG }-10 \\
\text { L5 laminectomy - } 5\end{array}$ & $\begin{array}{l}\text { Excellent - } 4 \\
\text { Good }-3 \\
\text { Fair }-3 \\
\text { Improvement of neurodeficit of } \\
\text { both pts }\end{array}$ & $\begin{array}{l}\text { Internal fixator does not } \\
\text { improve radiological } \\
\text { parameters }\end{array}$ \\
\hline Sahin $\mathrm{S}^{13)}$ & $\begin{array}{c}1 \\
(2005)\end{array}$ & $\begin{array}{l}\text { Jump from } 3^{\text {rd }} \\
\text { floor (due to } \\
\text { psychiatric } \\
\text { illness) }\end{array}$ & Severe LBP & $\begin{array}{l}\text { MIS L4-S1 fixation + } \\
\text { IR at } 4 \text { months }\end{array}$ & $\begin{array}{l}\text { Complete resolution of } \\
\text { symptoms \& restoration of } \\
\text { activity }\end{array}$ & $\begin{array}{l}\text { First MIS for } L 5 \text { burst } \\
\text { fracture: Effective } \\
\text { technique in selective } \\
\text { young pts where } \\
\text { conservative } R x \text { is not } \\
\text { an option }\end{array}$ \\
\hline Butler S." & $\begin{array}{c}14 \\
(2007)\end{array}$ & $\begin{array}{l}\text { Fall from } \\
\text { height }-7 \\
\text { RTA-3 } \\
\text { Agricultural } \\
\text { accident - } 1 \\
\text { Staircase fall - } 1 \\
\text { Heavy object } \\
\text { impact - } 1\end{array}$ & LBP - 14 & $\begin{array}{l}\text { Non-operative: } \\
\text { Early mobilization with } \\
\text { molded cast orthosis - } 10 \\
\text { Operative: } \\
\text { PD + L4-S1 Fixation - } 4\end{array}$ & $\begin{array}{l}\text { Superior radiological and } \\
\text { clinical outcomes with } \\
\text { non-operative Rx }\end{array}$ & $\begin{array}{l}\text { Largest ever series of } L 5 \\
\text { burst fractures: Strong } \\
\text { recommendation of } \\
\text { non-operative Rx in pts } \\
\text { with minimal deformity, } \\
\text { without neurological } \\
\text { deficit }\end{array}$ \\
\hline Ramieri $A^{12)}$ & $\begin{array}{c}19 \\
(2012)\end{array}$ & - & $\begin{array}{l}\text { LBP - 19, } \\
\text { L5,S1 Deficit: } \\
\text { Paralysis - 6, } \\
\text { Paresis - 13, } \\
\text { Bladder inv - } 12\end{array}$ & $\begin{array}{l}\text { PD + L4-S1 fixation + PLF- } \\
18 \\
\text { Circumferential fusion - } 1\end{array}$ & \begin{tabular}{|l|} 
Persistent LBP -4, \\
Complete neurological \\
recovery -5 \\
Distal paresis -3 \\
Distal paralysis -3 \\
Persistent isolated bladder inv -8
\end{tabular} & $\begin{array}{l}\text { Spinal canal } \\
\text { decompression }+ \\
\text { posterior stabilization } \\
\text { highly recommended for } \\
\text { neurological L5 burst } \\
\text { fractures }\end{array}$ \\
\hline Zeng ${ }^{16)}$ & $\begin{array}{c}1 \\
(2014)\end{array}$ & $\begin{array}{l}\text { Direct trauma } \\
\text { with heavy object }\end{array}$ & $\begin{array}{l}\text { LBP } \\
\text { B/L L5, S1 Paresis } \\
\text { B/L L5 Parasthesia }\end{array}$ & $\begin{array}{l}\mathrm{PD}+\mathrm{L} 5 \text { vertebrectomy }+ \\
\text { Reconstruction with } \\
\text { Titanium cage } \\
\text { Screw \& rod removal at } 1 \\
\text { year }\end{array}$ & $\begin{array}{l}\text { Complete recovery of } \\
\text { neurology. } \\
\text { ROM at LS junction improved } \\
\text { post-IR. }\end{array}$ & $\begin{array}{l}\text { Operative intervention a } \\
\text { must in neurological L5 } \\
\text { burst fracture. Should } \\
\text { be individualized for } \\
\text { every case }\end{array}$ \\
\hline Kim JK ${ }^{8)}$ & $\begin{array}{c}1 \\
\quad(2018) \\
\text { L2 \& L5 burst } \\
\quad \text { fractures }\end{array}$ & Fall from height & \begin{tabular}{|l|} 
LBP \\
Grade 2 power \& \\
hypoesthesia below L2 \\
level
\end{tabular} & $\begin{array}{l}\text { L1 \& L4 laminotomy + } \\
\text { Tapping of fracture } \\
\text { fragments }+ \text { L1-3 \& L4-S1 } \\
\text { PSSPSF } \\
\text { IR at } 1 \text { year }\end{array}$ & $\begin{array}{l}\text { Complete neurological } \\
\text { recovery at } 2 \text { years }\end{array}$ & $\begin{array}{l}\text { PSSPSF + tapping } \\
\text { technique - a good } \\
\text { alternative modality in } \\
\text { young patients to } \\
\text { preserve motion } \\
\text { segment }\end{array}$ \\
\hline Meyer $\mathrm{M}{ }^{10)}$ & $\begin{array}{c}6 \\
(2020)\end{array}$ & RTA - 6 & \begin{tabular}{|l|} 
LBP -6 \\
L5 paresis -4
\end{tabular} & $\begin{array}{l}\text { Step 1: } \\
\text { MIS L4-S1 fixation-2 } \\
\text { PD + L4-S1 fixation - } 4 \\
\text { Step 2: (after } 1 \text { week) } \\
\text { Ant L5 corpectomy + } \\
\text { Expandable cage + BMP }\end{array}$ & $\begin{array}{l}\text { Complete neurological } \\
\text { recovery - } 4 \\
\text { Intermittent pain - } 4\end{array}$ & $\begin{array}{l}\text { Alternative approach } \\
\text { with better kyphosis } \\
\text { correction \& } \\
\text { maintenance, but higher } \\
\text { morbidity of dual } \\
\text { approach }\end{array}$ \\
\hline
\end{tabular}

Abbreviations: LBP-Low back pain, RTA-Road traffic accident, MIS-Minimally invasive surgery, PD-Posterior decompression, IR-Implant removal, BG-Bone grafting, Ant-Anterior, Pts-Patients, F/b-Followed by, Rx-treatment, TLSO-Thoraco-lumbo-sacral Orthosis, PSSPSF-Percutaneous Short Segment Pedicle Screw Fixation 
anterior-only approach is adequate only when the posterior ligamentous complex is intact ${ }^{14)}$.

A railway accident as a mechanism of injury has not been previously described. Sahin et al first described minimally invasive stabilization (MIS) for an unstable L5 burst fracture in a poorly compliant patient with associated psychiatric illness, with implant removal performed at four months ${ }^{13)}$. They described MIS to be an effective technique in selective young patients, although the clinical and radiological outcomes were not described. MIS carries advantages of being a less morbid procedure with minimal blood loss, shorter hospital stay, facilita- ting early recovery and return to work ${ }^{10,13}$. Removal of implants has been described to preserve motion segment in cases treated without fusion, although ambiguity regarding the optimum time for the removal persists ${ }^{13)}$.

In our case, the patient had intractable radicular symptoms during movements due to the instability; hence MIS stabilization acted like an internal brace and resulted in immediate resolution of symptoms. Posterior decompression or vertebrectomy were avoided in view of the morbidity associated with these procedures. MIS has an advantage of motion segment preservation at the lumbosacral junction, although the disadvantage is requirement of an additional procedure of implant removal. Unlike thoracolumbar fractures, distraction ligamentotaxis is not advisable at the lumbosacral junction to maintain the segmental lordosis and in the presence of a reverse cortical sign ${ }^{7,13)}$. Partial remodeling occurred with residual loss of lordosis, mainly due to the adjacent disc degeneration and loss of disc space heights.

\section{CONCLUSION}

MIS temporary posterior stabilization can be considered as an alternative middle path in a young individual with $L 5$ burst fracture with predominant radicular symptoms refractory to conservative treatment, which allows early resumption of activities, helps to retain the lumbosacral motion segment; but with only partial canal remodeling and some residual loss of lordosis.

\section{CONFLICT OF INTEREST}

No potential conflict of interest relevant to this article.

\section{REFERENCES}

1. Butler JS, Fitzpatrick P, Ni Mhaolain AM, Synnott K, O'Byrne JM: The management and functional outcome of isolated burst fractures of the fifth lumbar vertebra. Spine (Phila Pa 1976) 32
(4):443-447, 2007

2. Brau SA, Delamarter RB, Schiffman ML, et al.: Vascular injury during anterior lumbar surgery. Spine J 4(4):409-412, 2004

3. Court-Brown CM, Gertzbein SD: The management of burst fractures of the fifth lumbar vertebra. Spine (Phila Pa 1976);12(3): 308-312, 1987

4. Finn CA, Stauffer ES: Burst fracture of the fifth lumbar vertebra. J Bone Joint Surg Am;74:398-403, 1992

5. Fredrickson BE, Yuan HA, Miller H: Burst fractures of the fifth lumbar vertebra. A report of four cases. J Bone Joint Surg Am; 64(7):1088-94, 1982

6. Holdsworth FW: Fractures, dislocations and fracture-dislocations of the spine. J Bone Joint Surg Am;54:6-20, 1963

7. Kaminski A, Muller EJ, Muhr G: Burst fracture of the fifth lumbar vertebra: Results of posterior internal fixation and transpedicular bone grafting. Eur Spine J 11(5):435-440, 2002

8. Kim JK, Bong Ju Moon, Sang-Deok Kim: Minimal invasive nonfusion technique for the treatment of noncontiguous lumbar burst fractures in young age patient: A case report. Medicine 97:10, 2018

9. McDonough PW, Davis R, Tribus C, et al.: The management of acute thoracolumbar burst fractures with anterior corpectomy and Z-plate fixation. Spine (Phila Pa 1976);29(17):1901-08, 2004

10. Meyer M, Noudel R, Farah K, et al.: Isolated unstable burst fractures of the fifth lumbar vertebra: Functional and radiological outcome after posterior stabilization with reconstruction of the anterior column: About 6 cases and literature review [published online ahead of print, 2020 Apr 27]. Orthop Traumatol Surg Res;S1877-0568(20)30133-X. doi:10.1016/j.otsr. 2020.03.014, 2020

11. Mick CA, Carl A, Sachs B, Hresko MT, Pfeifer BA: Burst fractures of the fifth lumbar vertebra. Spine (Phila Pa 1976);18(13): 1878-1884, 1983

12. Ramieri A, Domenicucci M, Cellocco P, Raco A, Costanzo G: Neurological L5 burst fracture: Posterior decompression and lordotic fixation as treatment of choice. Eur Spine J 21(Suppl 1):S119S122, 2012

13. Sahin S, Resnick DK: Minimally incisional stabilization of unstable L5 burst fracture. J Spinal Disord Tech 18(5):455-457, 2005

14. Sasso RC, Best NM, Reilly TM, et al.: Anterior-only stabilization of three-column thoracolumbar injuries [J]. J Spinal Disord Tech;18 Suppl:S7-14, 2005

15. Sasso RC, Kenneth Burkus J, LeHuec JC: Retrograde ejaculation after anterior lumbar interbody fusion: Transperitoneal versus retroperitoneal exposure. Spine (Phila Pa 1976);28(10):1023-1026, 2003

16. Zeng Hanbing, Wang Haibao, Xu Huazi: Complete L5 burst fracture treated by 270-degree decompression and reconstruction using titanium mesh cage via a single posterior vertebrectomy. Chinese Journal of Traumatology 17(5):307-310, 2014 